\title{
Model, Not Idol
}

\author{
The Recasting of the Image of Muhammad in Mukhtașar sīrat al-rasūl \\ by Muhammad b. Abd al-Wahhāb (d. 1792)
}

\author{
Martin Riexinger
}

Hitherto the academic study of "Wahhābism" - originally a derogatory term that will be used for the sake of convenience - has been primarily based on the study of a number of treatises of Muhammad b. 'Abd al-Wahhāb, in particular his Kitāb al-tawhìd (Book on God's unity) and Kashf al-shubūhät (Unveiling of what is unclear). These works had been written under difficult circumstances before Ibn 'Abd al-Wahhāb's alliance with the Āl Su'ūd resulted in a successful state formation. They are short and allegedly refer primarily to the Qur'ān and hadith and relatively little to writings of other scholars. This matter of fact has been used to belittle Ibn 'Abd al-Wahhāb's credentials as scholar, as he allegedly lacked sufficient knowledge of the scholarly tradition apart from the works of Ibn Taymiyya (d. 1328). ${ }^{1}$ This - problematic - image appears not least politically convenient as it allows dismissing violent aspects of Wahhābī teachings as not rooted in the scholarly tradition, if not as "un-Islamic".

In contrast to his mentioned earlier writings, Ibn 'Abd al-Wahhāb's most extensive work, Mukhtașar sirat al-rasūl (Abridgement of the life of the Prophet), hardly attracted attention until 2010, neither in publications on the early history of Wahhābism nor in general works on the biography and veneration of the Prophet. One reason for this might be that Brockelmann wrongly dismissed it as "extract (Auszug) from Ibn Hishām"; ${ }^{2}$ another one that neither state nor religious authorities in the third Saudi state were very eager to publish this text, for reasons to be discussed. The text was first printed in Egypt based on a manuscript of Sulaymān b. Suḥmān with whom Muḥammad Rashīd Rị̣ā had edited the compendium of Wahhābī writings, Majmū'at al-tawhìd (Collection on God's unity). ${ }^{3}$ This edition of the Mukhtașar was re-edited in

1 On the selection of sources already quoted in these works and in his correspondence, see Riexinger, "Der Islam", 32nıз.

2 Brockelmann, Geschichte der arabischen Litteratur, Supplementband II (GAL S II), 531; 'Abd al-Malik b. Hishām (d. 833), compiler of the most common abbreviation of the lost sìra of Ibn Isḥāq.

3 Ibn 'Abd al-Wahhāb, Mukhtașar, 236; Boberg, Ägypten, 253-57. 
Saudi Arabia in 1980. A new edition in 2004 follows that text but contains - in addition to remarks on the hadith quotations - a rejection of the affirmation of qișșat al-gharāniq (the "story of the cranes" or "satanic verses") by Ibn 'Abd al-Wahhāb. ${ }^{4}$

The few mentions in academic literature before my own contributions in 2013 and $2015^{5}$ are, besides Brockelmann, to be found in Chase Robinson's introduction to Islamic historiography, where he briefly characterises this sira as one example supposed to justify and encourage jihād. The other two examples were written by the Almohad authors Ibn Hubaysh and Kalāì but Robinson did not realise that Ibn 'Abd al-Wahhāb used the latter as a source for the Mukhtașar. ${ }^{6}$ In his article on the reception of qișșat al-gharānīq Shahab Ahmed points out that Ibn 'Abd al-Wahhāb was among the few authors in the later centuries who - against the current - accepted the episode as true. $\mathrm{He}$ asserts, however, that Ibn 'Abd al-Wahhāb's position differs from the affirmation of Ibn Taymiyya, for whom it served to exemplify his understanding of the prophets' infallibility ('ișma). As will be shown, he therewith misses completely the centrality of this episode in the Mukhtașar where it is mentioned twice. ${ }^{7}$ Furthermore, it also figures among the six most important episodes of the sira, to which Ibn 'Abd al-Wahhāb dedicated a short treatise, and will be used here to highlight those episodes that he considered particularly relevant. ${ }^{8}$ Recently the publication of the text by the Islamic State (ISIS, Daesh) has attracted media attention, but this has not yet resulted in academic studies. ${ }^{9}$

In the following it will be demonstrated that the Mukhtasar was written for the purpose to undermine prophetologic conceptions that were prevalent among Sunnī Muslims in Ibn 'Abd al-Wahhāb's lifetime; ideas which had come to dominate their understanding of the Prophet since the twelfth century. The centrepiece of these conceptions is the idea that Muhammad and the prophets preceding him possessed certain attributes, which elevated them beyond the status of ordinary humans. In Sufi circles it was furthermore held that God had bestowed on the awliy $\bar{a}$ properties which reflect those of the prophets on a lower level. Ibn 'Abd al-Wahhāb, however, did not write his account as a polemical treatise directly attacking the positions and arguments of specific authors. In the Mukhtașar, which was like many other works on the life and person of Muhammad directed at a broader audience than that of the

4 Ibn 'Abd al-Wahhāb, Mukhtașar (2004), $24 n 4$.

5 Riexinger, "Rendering Muhammad Human"; Riexinger, "Der Islam".

6 Robinson, Islamic Historiography, 123; Riexinger, “Der Islam”, 24-25, 35, 58.

7 Ahmed, "Ibn Taymiyyah", 117.

8 Ibn 'Abd al-Wahhāb, "Sittat mawāḍī'."

9 Croitoru, "Der Gründer”. 
'ulam $\bar{a}$, he works instead with selecting and discarding specific episodes and aspects of the sira in order to refute or emphasise elements that he objects to or considers central. As the main source of inspiration for much of the later devotional literature on Muhammad, al-Shifä bi-ta'rīf huqūq al-Muștafā (The healing through the determination of what the elect is entitled to) by Qâdī 'Iyāọ al-Yahṣubì (1083-1149) will be used as major reference for these positions, supplemented by some other works as well as by secondary literature. ${ }^{10}$ For the clarification of Ibn 'Abd al-Wahhāb's position, some other works by him and by the following generation of Wahhābì authors are taken into account. References to other puritan authors shall allow for an assessment of the position of Ibn 'Abd al-Wahhāb within the puritan Sunnī current. As I have elaborated on the sources of the Mukhtașar in 2015, they are primarily mentioned here where this contributes to the argument.11

The most salient aspect of the Mukhtașar is that the book deals twice with the lifetime of the Prophet but as well with much more than that. It begins with a long prologue covering elements of Islamic myth and history from the creation of Adam until the era of the Mongol invasions. The sira proper starts with the genealogy of Muhammad and ends with the early 'Abbāsid period, but also contains two "flashbacks" to Nūh (Noah) and the institutionalisation of polytheism in Mecca, respectively.

\subsubsection{Prophecy in Universal History: The Prologue}

The prologue starts with an introductory paragraph in which Ibn 'Abd al-Wahhāb praises the "stories of those before and after Muhammad" (qișas al-awwalin wa-l-äkhirin $)^{12}$ as "true armies of God" against which the enemies have no means of defence as they provide an array of examples for how God kept his promise to send messengers to mankind and to punish the disobedient. In addition, he introduces the hadith which came to serve as the slogan of Wahhābism: "Islam began as something strange, and as something strange Islam will return as it began" (bada'a l-islämu gharīban wa-sa-ya'ūdu gharīban $\left.k a-m \bar{a} b a d a^{\prime} a\right)$. Arguably it appears pertinent to translate 'ā $d a$ as a modal verb

\footnotetext{
10 Nagel, Allahs Liebling, 135-92; Schöller, Mohammed, 114-18.

11 Riexinger, "Der Islam".

12 Ibn 'Abd al-Wahhāb, Mukhtașar, 9; here äkhirīn seems to supplement the Qur'ānic asāțīr al-awwalīn (Q 6:25); see: Tottoli, Biblical Prophets, 13.
} 
with the meaning "to become again", but as it will become clear in this contribution Ibn 'Abd al-Wahhāb understands tradition in the sense of a triumphant return into a hostile environment. His understanding conforms to that of earlier reform movements such as the Almohads and that of Salafì and Jihādī circles at present. ${ }^{13}$

Beginning his account of the prophets with Ādam, Ibn 'Abd al-Wahhāb considers it as most important that, according to Q 7:172, all mankind was drawn out of his back and replied to the question "am I not your Lord?" with "Indeed, we bear witness". Ādam was then shown the supposed lifetimes of all prophets in the form of candles of different length. When he was told that only sixty years were destined for the lifetime of the prophet $D a \bar{u} u \bar{d}$, he donated him forty of his own one thousand years. This gift, however, he would later stubbornly deny when the angel of death appeared to him: "He forgot, as mankind forgot (its oath), Ādam denied, as they denied." Nine human generations after him would follow Islam. But then, out of an exaggerated love for the pious (ghuluww fi l-hubb al-șalihịin) due to the lack of scholarship, mankind began to commit shirk by erecting and adoring statues of them.

The correction of this deviation was to come with Nūh, but Ibn 'Abd al-Wahhāb points out that even after Nūh mankind relapsed into shirk. God responded by sending other prophets, many of whom are unknown or - as in the case of Șâliḥ and Hūd - difficult to locate in time and space. Nūḥ serves here to highlight what the author regards as the essential aspects of prophethood.

Whereas the construction of the Kaba is arguably the most important feat associated with Ibrāhīm in the Islamic tradition, another aspect ranks first in Ibn 'Abd al-Wahhāb's account. For him it seems to be more relevant that in three instances Ibrāhīm consciously did not say the truth according to a report in Șahịh al-Bukhärī: (1) when he simulated an illness before his kin (Q 37:89); (2) when he claimed that it was the largest of idols, and not he, who had destroyed the idols (Q 21:63); and (3) when he presented Sara to the tyrant ( jabbār) as his sister. ${ }^{14}$ Ibn 'Abd al-Wahhāb then quotes a long hadìth reported by Ibn 'Abbās on how Ibrāhīm together with his two sons Ishạ̄q and Ismāīl discovered the well of Zamzam, settled in Mecca, and erected the Ka'ba. God granted to Ibrāhīm that all future prophets would come from his offspring, although all but Muhammad came from the line of Isḥāq, not Ismāîil. ${ }^{15}$ Notably,

13 Ibn 'Abd al-Wahhāb, Mukhtașar, 9; Ibn Tūmart, Kitāb a'azz, 266-67; Yasin, "Powerful Lecture", 1:18-30 min.; "Salafitische Initiativen"; Riexinger, "Der Islam", 5-6.

14 Ibn 'Abd al-Wahhāb, Mukhtașar, 12-13.

15 Ibn 'Abd al-Wahhāb, Mukhtașar, 13-16. 
not all major prophets are treated in the prologue, as Mūsā and Īsā obviously could not serve as good examples for the punishment of unbelievers.

From the construction of the Ka'ba Ibn 'Abd al-Wahhāb proceeds to the introduction of polytheism to Mecca, which he ascribes to 'Amr b. Luhayy. Like the people to whom Nūh was sent, he acted out of misguided piety. He imported a statue of the god Hubal from Syria, installed it in the Ka'ba, and acquired the role of a priest-king. Meccans never completely abandoned the rites Ibrāhim had taught but added further ones which the authorities of the day approved of (istahsana) as a positive and thus permissible innovation (bid'a hasana). The purpose of the anachronistic use of figh terminology is to equate the idolaters of the past to Ibn 'Abd al-Wahhāb's opponents. The new practices also spread throughout the Hijāz. He explains the cult of al-Làt in accordance with a hadith as a practice that started with the veneration of the grave of a pilgrim who died on the way home from the hajj. As a result of such violations of the principle of tawhìd al-ulühiyya (discussed below) Islam became something strange again. ${ }^{16}$

As for the period before Muhammad's birth, Ibn 'Abd al-Wahhāb recounts in detail the idols for which each tribe or clan around Mecca was responsible. He denounces the leaders of the Quraysh who infused innovations (ibtada' $\bar{u}$ ) into the hajj-rites, as they considered the standing at mount 'Arafāt (wuqüf) not obligatory for the descendants of Ibrāhīm, and ruled that the Ka'ba should be circumambulated with all parts of the body uncovered except for the genitals. ${ }^{17}$

Ibn 'Abd al-Wahhāb then continues with the proofs for the divine message of Muhammad. The first thing that the Prophet enjoined was the belief in tawhid and not prayer. Accordingly, he regards the idea that nobody "who acknowledges the direction of prayer" (ahl al-qibla) may be denounced as unbeliever as flawed. He asserts on the contrary that Islam has always been met with little responsiveness, and in order to guarantee that Islam remains upright (yastaqim) the believers have to confront those who leave and dishonour this religion with hostility. This reflects most likely the controversy on this issue with Ibn 'Afālīq, the leading traditional Ḥānbalì scholar on the Peninsula between 1740 and 1745 . This is a hint that the text was written in the late 1740 s at its earliest. 18

\footnotetext{
16 Ibn 'Abd al-Wahhāb, Mukhtașar, 16-17.

17 Ibn 'Abd al-Wahhāb, Mukhtașar, 18-24.

18 Ibn 'Abd al-Wahhāb, Mukhtașar, 24-25; the preaching of tawhìd and the admonition against shirk are the first two of the "Sittat mawāeī"', 103-5; for the polemics against those who judge mildly those who do not pray, see: 31, 33, 35, 37; cf. Peskes, Muhammad $b$. 'Abdalwahhāb, 49-58, 83-89.
} 
One exception to such general reflections on Muhammad's prophethood in the prologue is the qișșat al-gharānīq, which is used by Ibn 'Abd al-Wahhāb in this instance to illustrate the concept of tawhid al-ulühiyya. For him the idea that anybody could possibly act as intercessor between God and man was explicitly refuted by the Qur'ānic verses related to this event. ${ }^{19}$ Furthermore, he stresses that true belief outweighs the bonds of kinship, ${ }^{20}$ and it manifests itself in acts. ${ }^{21}$ Another important, specific point for Ibn 'Abd al-Wahhāb is that Abū Ṭālib, Muhammad's uncle and the father of 'Alī, remained an unbeliever until his death and may not expect salvation in spite of his benevolence towards the Prophet and to the first Muslims (Q 9:113). Here he positions himself against the originally Shīī opinion that Abū Țālib was granted access to paradise. In the time of Ibn 'Abd al-Wahhāb, it seems that this idea had reached Sunnī, not least Sufi, circles, a matter that has not yet been studied in depth. ${ }^{22}$ It is noteworthy that the outstanding anti-Wahhābi author of the mid-nineteenth century Aḥmad Zaynī Daḥlān wrote a defence of Abū Țālib's salvation, titled Asnā̄al-mațālib fìnajāt Abī Tălib (Excelling claims concerning the question whether Abū Taalib was saved). It was directed against a treatise by a certain Muḥammad b. Ḥasab Allāh whose opposing views had caused a scandal in Mecca. ${ }^{23}$ Throughout this section, Ibn 'Abd al-Wahhāb connects the text again to present issues with the help of an anachronistic language use. Both Meccan Qurayshī and Medinan Jewish opponents of the Prophet are referred to as 'ulamä'.

In the discussion of the ridda, Ibn 'Abd al-Wahhāb goes into detail regarding the transgressions for which the tribes that gave up Islam after the death of Muhammad were to blame. He stresses that all of them were punished with death and confiscation of property in case they did not repent. Their treatment at the companions' hands thus belies the assertions of contemporary 'ulam $\bar{a}$ ' that Bedouins who do not pray and even deny resurrection may not be persecuted as long as they pronounce the first part of the shahäda. Punishment was even meted out against the Banū Hānīfa who committed the worst transgressions under the ridda, although they prayed and professed the belief in God. But their example is also used to demonstrate that active repentance - in this case their eager participation in jihād under the rāshidūn - cleanses off the stain of the ridda. ${ }^{24}$

\footnotetext{
19 Ibn 'Abd al-Wahhāb, Mukhtașar, 25-26.

20 Ibn 'Abd al-Wahhāb, Mukhtaṣar, 26-27.

21 Ibn 'Abd al-Wahhāb, Mukhtaṣar, 28.

22 Ibn 'Abd al-Wahhāb, Mukhtașar, 25; Ibn 'Abd al-Wahhāb, "Sittat mawāḍī", 106.

23 Rubin, "Abū Țālib"; Brockelmann, GAL S II, 500-501.

24 Ibn 'Abd al-Wahhāb, Mukhtașar, 29-33; Ibn 'Abd al-Wahhāb, "Sittat mawādīi", 108-10.
} 
Ibn 'Abd al-Wahhāb then turns to the appearance of extreme deviation in religious thought (ghuluwww) during the Umayyad and early 'Abbāsid periods. In the case of Mukhtār b. Abī 'Ubayd al-Thaqafì he points out that he prayed and took care that the law was applied in the territories entrusted to him, but when he claimed divine inspiration, the 'ulama $\bar{a}^{3}$ unanimously considered him an unbeliever. The same was the case with Jad $b$. Dirham, who had been highly estimated for his orthopraxy and his knowledge, but once he denied certain attributes of God and that God had not taken Ibrāhīm as walı and not spoken to Ādam and Mūsā, his pious practice became irrelevant for the assessment of his faith. Ibn 'Abd al-Wahhāb stresses that those who hold such positions are far worse than the Christians and Jews and hence deserve to be burnt alive unless they repent. ${ }^{25}$

Ibn 'Abd al-Wahhāb then skips several centuries and points out that the Banū 'Ubayd (Fāțimids, ruling in Egypt 969-1171) spread unbelief and hypocrisy while they adhered to the rites of Islam. Therefore, all 'ulam $\bar{a}$ ' denounced them as unbelievers and rejoiced when Șalāh al-Dīn (r. 1174-93) put an end to their rule. The last example he refers to are the Mongols who began to pray after their mock conversion to Islam but did not accept the sharīa as a whole. Therefore, some 'ulam $\bar{a}$ ' opposed them until they were expelled from the realm of the Muslims. Ibn Taymiyya is not mentioned by name, but the hint to his fatwa against the Mongol rulers of Mardin is unmistakable. ${ }^{26}$

Ibn 'Abd al-Wahhāb concludes the prologue with the accusation that the 'ulam $\bar{a}$ ' of his time insist that somebody who says lā ilāha illa Llāh may not be called unbeliever, although all the examples to the contrary are to be found in the very books they refer to. ${ }^{27}$

\subsubsection{The Sīra Proper}

2.1.2.1 Ancestors and Events Shortly before Muhammad's Birth

The sira proper is preceded by an account of the campaign of the Aksumite army general Abraha against the Kaba, which was protected against the Ethiopian assault by birds throwing stones on the army, thus irritating the war elephants, and the punishment of Abraha with a deadly disease thereafter. Ibn 'Abd al-Wahhāb also mentions Muḥammad's paternal grandfather, Abū Hāshim 'Abd al-Muțțalib, his father, 'Abd Allāh (with special consideration of

25 Ibn 'Abd al-Wahhāb, Mukhtașar, 34-35. On Mukhtār al-Thaqafī, see Halm, Shi ism, 16-18; on Ja'd b. Dirham, see van Ess, Theologie, 2:449-58, 4:388-89.

26 Ibn 'Abd al-Wahhāb, Mukhtașar, 36 -37. On the recent reception of Ibn Taymiyya's fatwa in Jihādī circles and its importance for them, see Michot, Muslims; Said, "Konferenz".

Ibn 'Abd al-Wahhāb, Mukhtașar, 38 . 
his role in the erection of the Kaba), and his paternal uncle Abū TTâlib. His mother, Âmina, seems not to be worthy of consideration. ${ }^{28}$

\subsubsection{The Meccan Phase}

The conception and birth of the Prophet as well as their circumstances are passed over in a stark contrast to the importance of these aspects in other sira works and in the devotional literature about Muhammad. Moreover, events usually associated with the childhood of the Prophet, in particular the opening of his thorax by two angels who purified and weighed his heart, are not mentioned. The first event from Muhammad's life reported is his participation in the mercantile expedition led by Abū Țālib to Syria, where they encountered the monk Bahīrā who warned the party to protect Muhammad from the Jews. It is neither mentioned that he discovered the mark of prophethood between his shoulders, nor that trees and stones expressed their veneration for Muhammad. The marriage to Khadija and further expeditions to Syria are related. Ibn 'Abd al-Wahhāb then recounts that Muhammad began to seek reclusion at Hirä' because he wanted to come close to God and to distance himself from the detested idolatry. ${ }^{29}$ Much space is dedicated to the restauration of the Kaba. After it had been damaged by a flood or landslide, Muhammad participated in the rebuilding, and he was the one chosen to put the black stone in its place. One event that shows Muhammad in a less favourable light is referred to as well: like others, he took his loincloth off to bolster his shoulders while carrying stones. As a result, his genitals became visible which earned him a reprimand by "someone", whereupon his private parts were never again to be exposed to any unbecoming spectator. Regarding this episode he follows Ibn Sa'd as well as Ibn al-Jawzī, but does not specify the person reprimanding Muhammad, which is mentioned by both as Abū Ṭālib. ${ }^{30}$

After this episode Ibn 'Abd al-Wahhāb comes back to Nūh as the archetypical prophet, and once more recounts the introduction of paganism in Mecca, apparently in order to contrast it with Muhammad's prophethood. The generational model of an establishment and decay of Islam is repeated, as are also the etymological legends for the cults of the various gods, to which he provides some additions. It is equally stressed again that the rites of the din Ibrähim were never completely abandoned. ${ }^{31}$

\footnotetext{
28 Ibn 'Abd al-Wahhāb, Mukhtașar, 39-48.

29 Ibn 'Abd al-Wahhāb, Mukhtașar, 48-49.

30 Ibn 'Abd al-Wahhāb, Mukhtașar, 49-51; Ibn Sa'd, Țabaqāt, 1:93-95; Ibn al-Jawzī, Muntazam, 2:320-27.

31 Ibn 'Abd al-Wahhāb, Mukhtașar, 51-56.
} 
The account of the first revelation, based on the report ascribed to 'Ā'isha, is presented by Ibn 'Abd al-Wahhāb as a decisive confrontation with paganism. He quotes Ibn Qayyim, who states that Muhammad was told to address an evergrowing audience, starting from his immediate environment, then extending his call to the Arabs in the vicinity, thereafter to the Arabs as a whole, and finally to both worlds of mankind and jinn. Ibn 'Abd al-Wahhāb adds that God ordered him to practise da'wa peacefully for ten years, until he allowed him emigration (hijra) and to fight against those who fought him, before engendering upon him to fight all those who associate someone else with God. ${ }^{32}$

Ibn 'Abd al-Wahhāb continues by naming those who first responded to Muhammad's call, without delving into the question of priority. According to him, the Quraysh were first not aware that Muhammad was proselytising, until they realised that the idols were reviled by Sumayya, the mother of 'Ammār b. Yāsir, who became the first martyr when Abu Jahl killed her with a lance. When Muhammad publicly came forth with his $d a^{\prime} w a$ in the fourth year, this led to fighting during which Sa'd b. Abī Waqqāṣ for the first time shed blood in the name of Islam when he beat up one of the mushrikūn. ${ }^{33}$

By referring to the plight of the first Muslims in the face of Quraysh persecution and to the first emigration to Ethiopia, Ibn 'Abd al-Wahhāb prepares for the second discussion of the qișsat al-gharāniq in the text. He insists that the wording came from Satan but was physically uttered by Muhammad (alqa 'alā lisānihi), upon which the Meccan pagans prostrated. The revocation of the verses then led the Quraysh to intensify the persecution of Muhammad and the Muslims. ${ }^{34}$ Thereafter the conversion of 'Umar, the death of Khadija, and the confirmation of Jewish scholars on the rūḥ and the Seven Sleepers are briefly mentioned. ${ }^{35}$

The splitting of the moon, narrated as the central miracle of confirmation (mи jiza), is treated rather briefly, as responding to the accusation of Muhammad being a poet and magician. It is followed by elaborations on the relevance of miracles for prophethood, which will be dealt with later. ${ }^{36}$ As for the stories of $i s r \bar{a}$ ' and mi'rāj, Ibn 'Abd al-Wahhāb further abridged the already short description in Ibn Qayyim al-Jawziyya's Zād al-ma'ād. His presentation thus contrasts already starkly with Ibn Hishām but also with Ibn al-Jawzī, not to speak of later works. He mentions:

\footnotetext{
32 Ibn 'Abd al-Wahhāb, Mukhtașar, 57-58; Ibn Qayyim al-Jawziyya, Zād, 1:2o.

33 Ibn 'Abd al-Wahhāb, Mukhtaṣar, 59-61.

34 Ibn 'Abd al-Wahhāb, Mukhtașar, 62-68; with regard to qișșat al-gharānīq (63) he follows the wording in Ibn Sacd, Tabaqāt, 1:137.

35 Ibn 'Abd al-Wahhāb, Mukhtașar, 68-76.

36 Ibn 'Abd al-Wahhāb, Mukhtașar, 77-82.
} 
1. The nocturnal ride on Burāq

2. Muhammad leading the prayer of the prophets

3. The encounter with the earlier prophets

4. The vision of the saved in heaven and the damned in hell

5. Mūsā's envy because more members of Muhammad's umma than of his own will enter paradise

6. The view of al-bayt al-ma'mūr ( $\mathrm{Q} 52: 4)$ and sidrat al-muntahā (Q $53: 14)$

7. The reduction of the numbers of daily prayers from fifty to five ${ }^{37}$

After the depiction and discussion of these miracles, which did not impress the Meccans, Ibn 'Abd al-Wahhāb relates the negotiations with the Medinan tribes of the Aws and Khazraj, which led to the hijra but also ended a 120-year feud between them, an occasion to stress the pre-eminence of the commitment to Islam over blood ties. ${ }^{38}$

In the context of the hijra two further miracles of the Prophet get mentioned: the blessing of the emaciated sheep of Umm Ma'bad, which then gives milk to Muhammad, and this Bedouin woman who praised him for it. The author remarks that Umm Macbad exalted the Prophet and his physical traits but did not ascribe anything to him that would elevate him beyond the status of an ordinary human. The other miracle is a poem in praise of him, which was heard over Mecca. ${ }^{39}$ Events mentioned in relation to the arrival and settlement in Medina are the construction of the mosque, the marriage with 'A'isha, which in breach of the jāhiliyya conventions was concluded in the month Shawwāl, and finally the fraternisation of the muhājirūn and anșār, which again brings out the priority of religious over family ties. ${ }^{40}$

\subsubsection{The Medinan Phase}

With the Medinan phase Ibn 'Abd al-Wahhāb starts to present the course of events in an annalistic style. At the end of each year, he lists eminent persons who passed away during it, a feature that shows the strong formal influence of Ibn al-Jawzīs al-Muntazam fi ta'rīkh al-umam wa-l-muluk (The well-ordered

37 Ibn 'Abd al-Wahhāb, Mukhtașar, 83-84; Ibn Qayyim al-Jawziyya, Zād, 1:47-48; cf. Ibn Hishām, Sìra, 1:403-8; Ibn al-Jawzī, Muntazam, 3:25-32; Ibn al-Jawzī, Wafä', 218-24; Qasțallānī, Mawāhib, 2:339-98; Vuckovic, Heavenly Journeys, 47-72; Schöller, "Biographical Essentialism", 167. "The visited house" and "The lote tree of the outer limit" mentioned under (6) are two enigmatic Qurānic terms mostly interpreted as a heavenly correspondent of the Ka'ba and a plant in the highest heaven, respectively, on the basis of the mirāj traditions.

38 Ibn 'Abd al-Wahhāb, Mukhtașar, 84-91.

39 Ibn 'Abd al-Wahhāb, Mukhtașar, 94-95.

40 Ibn 'Abd al-Wahhāb, Mukhtașar, 98-101; the central importance of the hijra is also highlighted by the fact that it is one of the "Sittat mawāọī", 106-8. 
work on the history of the nations and rulers), one of the major sources of the Mukhtasar..$^{41}$ In this section the thematic scope becomes very narrow: Ibn 'Abd al-Wahhāb focusses on the military campaigns, the abolition of pagan rites after conquests, and some central revelations. He passes over other aspects, as, for example, Muhammad's further marriages and his domestic life. To Muhammad's special qualities (khașä̉iș) he dedicates a special paragraph. But even in these passages he emphasises his abilities as leader. ${ }^{42}$ Nevertheless two events which are not related to conquests are presented and they must hence be considered to be of central importance for the work in general: the so-called necklace affair, and the conversion of the poet Kac $b$ b. Zuhayr and his praise of Muhammad's military abilities in his famous panegyric Bānat Su'ãd. ${ }^{43}$

After listing the first skirmishes Ibn 'Abd al-Wahhāb mentions how 'Amr b. al-Hadramī was killed as the first opponent of Islam. ${ }^{44}$ The battle at Badr is then recounted extensively, with a final narration of a miracle of the Prophet: he threw a handful of sand in direction of the enemies, which was carried by the wind and thoroughly impaired the eyes of those who were touched by it. ${ }^{45}$ The defeat at Uhud is given equal attention, its unfavourable outcome explained with an intervention of Satan. ${ }^{46}$

Whereas the defeat of the Jewish tribes in Medina is reported without much detail or explanation, the conquest of Mecca has a central position in the work. Muhammad expresses his disgust at statues of Ibrāhīm and Ismāíil with oracle arrows in the Kaba and orders the idols to be smashed. Only after it has been converted into a mosque and Bilāl has called to prayer he enters the building. The description of the purification of the Kaba is supplemented by the reports on the expeditions of 'Amr b. al-'Āṣ and Sa'd b. Zayd, respectively, in which they destroyed the idols of Sawā' and the statue of Manāt and eradicated the cults related to them. ${ }^{47}$ This triumph is, however, followed by the campaign against the Banū Hawāzin who were defeated, accepted Islam, and underlined this by their commitment to prayer. As they soon afterwards (i.e. after Muhammad's death) gave up Islam again, the Muslims had for the first time "to taste the bitterness of defeat". 48

\footnotetext{
41 Riexinger, "Der Islam", 19.

42 Ibn 'Abd al-Wahhāb, Mukhtașar, 105-5.

43 Ibn 'Abd al-Wahhāb, Mukhtașar, 161-63; Sells and Sells, "Bānat Su'ād".

44 Ibn 'Abd al-Wahhāb, Mukhtașar, 106-7.

45 Ibn 'Abd al-Wahhāb, Mukhtașar, 108-13.

46 Ibn 'Abd al-Wahhāb, Mukhtașar, 115-20.

47 Ibn 'Abd al-Wahhāb, Mukhtașar, 140-149.

48 Ibn 'Abd al-Wahhāb, Mukhtaṣar, 149-55.
} 
Another event of central importance is the siege of TTâiif and its consequences. As the siege did not lead to a victory for the Muslims, and nor did the Banū Thaqif see the possibility to resist the Muslims for a long time, they sought negotiations. Muhammad rejected their proposal because it implied a three-year period during which the cult of al-Lăt should remain permitted. To this episode Ibn 'Abd al-Wahhāb adds a digression on "the legal aspect of the Tâa'if campaign", where he describes the pagan cults with a figh terminology which was used to legitimise the veneration of graves. He asserts that none of the pagans believed that the respective gods had created the world and were sustaining it. Nevertheless, they were adored in imitation to established custom $($ taqli $d)$. Truth thus was weakened whereas unbelief grew stronger. Such places are, however, never to be tolerated. By alluding to the hadith "Islam began as something strange" he concludes stating that groups who eliminate such innovations would time and again turn up. ${ }^{49}$

The account of the Tabük campaign, the first conquest beyond the limits of the Arabian Peninsula, appears markedly in a less triumphalist way. The widespread disinclination to participate in jihäd during the summer heat close to the date harvest was reprimanded and overcome by the revelation of Q 9:8. This serves Ibn 'Abd al-Wahhāb as an occasion to highlight the centrality of jihād in Islam..$^{50}$ In his account of the tribal delegations of tribes which arrived in Medina for declaring their submission to Muhammad and their allegiance to Islam, he mentions the pseudo-prophet Musaylima among those who came along with the Banū Hanīfa and claims that he was already at this point in time exposed by Muhammad. ${ }^{51}$

The final illness of Muhammad and his death, as well as the succession of Abū Bakr after the negotiations at the saqīfa (veranda), are rather briefly treated. He stresses that Abū Bakr was acclaimed as caliph because of his ability to uphold the Islamic realm and guarantee the implementation of the Islamic norms. This reflects the theory of Islamic government as presented by Ibn Taymiyya, according to which leadership is legitimised by the ruler's ability to expand the realm of Islam and to reinforce its rules within it. ${ }^{52}$

\subsubsection{The Ridda}

After his narration of the life of the Prophet, Ibn 'Abd al-Wahhāb turns to the topic of the ridda, to which he dedicates the largest portion of his work

49 Ibn 'Abd al-Wahhāb, Mukhtașar, 155-59.

50 Ibn 'Abd al-Wahhāb, Mukhtașar, 164-69.

$5^{1} \quad$ Ibn 'Abd al-Wahhāb, Mukhtașar, 170-74.

52 Ibn 'Abd al-Wahhāb, Mukhtașar, 174-82. 
(30 of 229 pages in the edition used). He starts his account by listing the various forms in which different tribes apostatised, and he stresses once more the necessity to fight apostates until they repent by pronouncing both parts of the shahāda, accepting to pray, and to pay zakāt. Nevertheless, Abū Bakr had to face appeasers who tried to convince him to show mercy and to wait until everything would calm down again, against which he objected that the duty to wage jihād had not ceased with the Prophet's death. Furthermore, he mentions that 'Umar finally convinced Abū Bakr not to participate in the campaigns himself, as his possible death in battle might lead many fighters to defect. A justification of Ibn 'Abd al-Wahhāb's retreat to Dir'iyya?53

As source for his account Ibn 'Abd al-Wahhāb refers to Wāqidī's Kitāb al-ridda, which, however, was most likely lost by then. It is extensively referred to by the Almohad historian Ibn Hubaysh (504/1111-584/1188) in his Kitāb al-ghazawāt al-d̄amina al-käfila and in its abridged version titled Kitāb al-iktifä̀ bi-mā taḍammanahu min maghāzī rasūl Allāh wa-maghāzīal-thalātha al-khulafä̀) authored by his pupil Kalāī (565/1170-634/1237). The dependence on Kalā'i is discernible by the order of events, by certain poems, and, most relevant in our context, by the fact that the activities of the pseudo-prophet Musaylima are treated as something that happened during the ridd $a$ and not during the lifetime of Muhammad. ${ }^{54}$ Both these Almohad texts share with the Mukhtașar the intention to justify jihād against persons who declare themselves as Muslims, implying that it is permitted to kill them and to confiscate their property. ${ }^{55}$ The adoption of an Almohad text by Ibn 'Abd al-Wahhāb is remarkable as even Ibn Taymiyya abhorred this movement and issued a fatwa condemning Ibn Tūmart's indiscriminate use of violence. ${ }^{56}$

A characteristic trait of the ridda narrative is the unrelenting description of the violence meted out to the apostates, including massacres in which whole clans were burnt alive. In the Mukhtașar these reports as juxtaposed here and in later sections with examples of those who returned to the straight path and in some cases even played an important role in the expansion of Islam. The violence is justified with the fact that the appalling news motivated some tribes to return to Islam. ${ }^{57}$ Details concerning the specific aspects of each tribe's apostasy are only briefly listed, as are details about the

\footnotetext{
53 Ibn 'Abd al-Wahhāb, Mukhtașar, 184-87.

54 Dunlop, "Ibn Hubaish"; Pellat, "al-Kalāīī. For further details see Riexinger, "Der Islam”, 24. On the diverging chronology in Ibn Hubaysh's account, see Al Makin, Representing the Enemy, 102.

55 Ibn Tūmart, Kitāb a'azz, 261-66; Urvoy, "La pensée", 32-33.

56 Laoust, "Une fetwâ".

57 Ibn 'Abd al-Wahhāb, Mukhtașar, 184-209.
} 
campaigns. A conspicuous exception is the role Musaylima is supposed to have played among the Banū Ḥānīfa. Ibn 'Abd al-Wahhāb narrates in accordance with the Ibn Hubaysh/Kalāi tradition that Musaylima used to bless the newborns and to pray for the sick, and that people addressed him with requests for miraculous help. One example is a rich father who saw all his sons die before they came of age. He then asked Musaylima to pray for his two sons to survive. The next day the elder one fell into a well and drowned whereas the newborn was lying in agony. Another example is that a well that Musaylima had blessed became salty immediately. ${ }^{58} \mathrm{Ibn}$ 'Abd al-Wahhāb's presentation of Musaylima contrasts with other traditions where Musaylima's activities are placed in the lifetime of Muhammad for the first place, and where his thaumaturgical claims are explained by his tribesmen urging him to do "like Muhammad". ${ }^{59}$

\subsubsection{Further Events after the Ridda}

From the ridda Ibn 'Abd al-Wahhāb proceeds to the ensuing conquests beyond the Arab Peninsula, but in a striking contrast with the campaign against the ridda he mentions them rather in passing, as if to convey the message that the internal consolidation of Islam was much more relevant than the external expansion. Both aspects are connected in the mention of the repentant pseudo-prophet Țulayha, who fell in the jihäd against the Persian Empire, as one of the important events under the caliphate of 'Umar. ${ }^{60}$

Accusations of nepotism, which do often explain the opposition to 'Uthmān, are not repeated by Ibn 'Abd al-Wahhāb. Instead, he explains the rift among the Muslim community that started under his reign with political dissatisfaction among the Kufans, which was exacerbated by the conspiracies of the converted Jew 'Abd Allāh b. Saba'. He anachronistically calls the assassins of the third caliph mujrimūn khärijiyyūn, and thus anticipates the fragmentation that was to ensue from the following events. ${ }^{61}$

According to Ibn 'Abd al-Wahhāb, 'Alī came forth with the claim to be caliph after 'Uthmān's death, but only after the ahl al-Badr had pledged allegiance to him. He thus discounts the Shīi allegation that his claim was based on a designation by Muhammad. He briefly mentions Mu'āwiya's refusal to pledge allegiance to him, implying his intention to revolt. But the account then moves quickly on to the Battle of the Camel, which according to him started after 'Ā'isha's emissaries Ṭalha and Zubayr had been expelled from Basra and her

\footnotetext{
58 Ibn 'Abd al-Wahhāb, Mukhtașar, 196-98.

59 Riexinger, "Der Islam", 38-39.

6o Ibn 'Abd al-Wahhāb, Mukhtașar, 215-19.

61 Ibn 'Abd al-Wahhāb, Mukhtașar, 220-26.
} 
attempt at reconciliation had failed. Ibn 'Abd al-Wahhāb then claims that it was the Khārijites, instigated by 'Abd Allāh b. Saba', who were to be found in both camps and who provoked fighting, which without them would not have taken place. ${ }^{62}$ In the context of the battle he mentions another miracle. After 'Ā'isha's camel had collapsed, Muhammad b. Abī Bakr, who was supposed to guard her, sacrilegiously extended his hand into her howdah, to which she responded saying, "the one to whom belongs this hand violates the haram of the Messenger and shall be punished!" to which the malefactor responded, "with the fire of this world or the next world?" upon which she responded, "No, from this world!" whereat his hand was burnt off immediately. Ibn 'Abd al-Wahhāb then stresses that 'Alī treated 'Â'isha respectfully and let her return to Medina. ${ }^{63}$

About the Battle of Șiffin he shortly notes only the most important aspects, whereas he dedicates much more attention to one event in its aftermath, that is, the address of 'Alī's emissary Ibn 'Abbās to the Khārijite defectors in their camp at Ḥarūrā'. Being asked which acts of 'Alī they object to, they responded: 1. The mediation contradicts Q 12:40.

2. Had the opponents been believers, it would have been unlawful to combat them; if they were unbelievers, however, it would have been permitted to persecute them, to take them as prisoners, and to take their property. But 'Alī allowed neither to take prisoners nor booty.

3. He accepted to abstain from using the title amir al-mu'minin.

Ibn 'Abbās responded to (1) that the Qurān encourages to mediate in case of marital disputes and the danger of retaliation and to (3) that the Prophet had abstained from using the title rasül Allāh for tactical reasons. To objection (2), which is lacking in many accounts other than Ibn al-Jawzīs, Ibn 'Abbās replied that, with 'A'isha, one of the ummahāt al-mu'minin was on the battlefield. Would they, then, enslave their mothers and have intercourse with them? After this argument, all but a few repented. ${ }^{64}$

After this episode Ibn 'Abd al-Wahhāb briefly mentions the insurrection against 'Alī by the remaining Khārijites, without naming Nahrawān, and his assassination by Ibn Muljam. Hasan is praised for giving up his claim for the caliphate and it is argued that his stance was preferable to that of his father, as he too should have acknowledged that he had a majority against him. Nevertheless, one should not denounce followers of one camp as

\footnotetext{
62 Ibn 'Abd al-Wahhāb, Mukhtașar, 226-27.

63 Ibn 'Abd al-Wahhāb, Mukhatșar, 227.

64 Ibn 'Abd al-Wahhāb, Mukhtașar, 228-29; Ibn al-Jawzī, Muntażam, 5:124-25; Riexinger, "Der Islam", 29-30.
} 
unbelievers - this term should be reserved for the Khārijites - but nonetheless the most praiseworthy are those who abstained from siding with one of them. Husayn's death at Karbalā' is briefly mentioned, as is also the second fitna, with regard to which Ibn 'Abd al-Wahhāb does not express any preferences. Under 'Umar b. 'Abd al-'Azīz the community supposedly returned for a brief period to circumstances similar to those under the Rightly Guided Caliphs, whereas with Ja'd b. Dirham somebody claimed for the first time that the Qurann was created. According to Ibn 'Abd al-Wahhāb, Yazīd b. al-Walīd was the last generally accepted caliph, and the umma has never recovered from the split that the third fitna (i.e. the overthrow of the Umayyads in $75^{\circ}$ ) had caused. ${ }^{65}$

In the early 'Abbāsid period, the author discerns all the problems which in future were to haunt the Muslims. As the main culprit he singles out Ma'mūn, who had Greek books translated while true Muslims like Ahmad b. Hanbal were subjected to the mihna. The Mukhtașar closes with a remark about the decay of scholarship due to becoming text based, a process that had started under Manșūr, when tafsìr and hadìth (Mālik b. Anas, 'Amr al-Awzāìi, Sufyān al-Thawrī, Ma'mar b. al-Muthannā), ra’y (Abū Ḥanīfa), and maghāzī (Wāqidī) were written down. ${ }^{66}$ For the question of why Ibn 'Abd al-Wahhāb finishes the Mukhtașar with such a rant against the text's own prerequisites I cannot yet offer a satisfying explanation.

\subsection{Objectives of the Mukhtasar}

The Mukhtașar has two interconnected main objectives. For the first, this sïra is obviously designed to justify concrete policies of Ibn 'Abd al-Wahhāb and his Âl Su'üd allies, as well as to ward off criticism of their position. The other objective is to formulate a puritan prophetology which is embedded in a circular (or better undulate) concept of history and supposed to serve as a general legitimisation of the Wahhābī project of religious reform.

\subsubsection{The Justification of Specific Measures}

An iterating topic in the Mukhtașar is the well-known Wahhābī concept of tawhìd al-ulühiyya and the idea that its violation is to be considered shirk amounting to apostasy. This is reflected in many instances where Ibn 'Abd al-Wahhāb remarks that the mushrikūn do not deny the existence of God and his status as the Highest Lord, but that they rather violate his rights by asking

65 Ibn 'Abd al-Wahhāb, Mukhtașar, 230-35.

66 Ibn 'Abd al-Wahhāb, Mukhtașar, 235-36. 
beings inferior to him for intercession. One prominent example is the double affirmation of qișșat al-gharānīq, where the concept of praying for shafäa, held by Muhammad's Qurashī opponents, is contrasted with Islam. Another one is the digression on the legal content of the campaign against Tầif, where Ibn 'Abd al-Wahhāb equates the pagan rites and their institutionalisation with anachronistic terms derived from figh and Sufism, in order to demonstrate how reprehensible the veneration of graves is, leading to the conclusion that such practices are to be abolished immediately.

By choosing Ibn al-Jawzī's version of Ibn 'Abbās's speech to the Khārijites at Hāāurā', Ibn 'Abd al-Wahhāb addresses a legal issue as well. The second objection, that 'Ali did not allow the combatants in the Battle of the Camel to make prisoners and booty, is lacking in most other accounts of the event. Ibn 'Abbās explains this prohibition by alerting to one specific circumstance: with 'Á'isha, one of the ummahāt al-mu'minin, present on the battlefield, enslaving her, and - implicitly - thereafter having sex with her would be like fornicating one's own mother. The selection seems to have been motivated by the intention to dismiss the use of 'Alì's injunction in the Battle of the Camel as a valid example for one legal objection which was raised against Ibn 'Abd al-Wahhāb and his allies: the distinction between $j i h \bar{a} d$, where prisoners and booty may be taken, and the struggle against Muslim rebels (bughāt), who are supposed to be repelled and impeded, but who shall not be persecuted and captured. ${ }^{67}$

\subsubsection{The Transformative Reformulation of Prophetology}

\subsubsection{Undermining the Mawlid-Complex: The Denial of the Prophet's Pre-existence}

The insistence on Âdam as the first human and the neglect of the begetting, birth, and childhood of Muhammad are intimately related. With both, Ibn 'Abd al-Wahhāb tries to undermine the belief in the pre-existence of Muhammad as a divine light preceding all other creation. This concept is perhaps the most salient aspect of the devotion for the Prophet Muhammad that began to flourish in the eleventh century. The transmission of the Prophetic light completed with 'Abd Allāh's impregnating of Āmina, as reported in Ibn Hishām, does not imply the concept of Muhammad's pre-existence, but in the course of the centuries and most likely under the influence of Shīì prophetology and imamology this idea gained ground in Sunnī circles. ${ }^{68}$ The concept has also led

67 Abou El Fadl, Rebellion, 34-37.

68 Rubin, "Pre-existence"; Katz, Birth, 13-24; Nagel, Allahs Liebling, 157-58; the question of the nūr muhammadī and Muhammad's pre-existence was a central controversial issue between puritans and Sufis: Riexinger, Șanāullāh Amritsarī, 243; Preckel, "Islamische 
to the development of new rituals. Given that Muhammad is conceived of as pre-existent, his birthday is worth being commemorated as the manifestation of this light in the earthly world. ${ }^{69}$ The most important expression of these beliefs is therefore the celebration of Muhammad's birthday, a tradition that emerged among Sunnīs in Syria and the Arabian Peninsula in the late twelfth century, most likely inspired by the state-sponsored celebration under Fāțimid and/or Twelver Shīī practices, although no definite proof for this has been established. The Shīi connection was harped upon by Sunnī opponents of the mawlid. ${ }^{70}$ In the course of centuries its celebration spread among Muslims in all regions, and it played a particular role in many regions to which Islam came in close connection with Sufism. It was, however, constantly resented by puritans like Ibn Taymiyya who denounced it as bid'a together with other placeand time-related rituals apart from Eid al-Adha and Eid al-Fitr. ${ }^{71}$

A typical element of mawlid-related poetry is the emphasis on the begetting, birth, and childhood of Muhammad associated with the mentioned variety of ominous signs, whereas his life in the phase of prophethood gets little attention. Related to the denial of Muhammad's luminal pre-existence are miraculous events linked to his conception like Āmina's pregnancy, during which she saw the city of Bosra, and the idols breaking and the holy flames extinguishing at the moment of his birth. ${ }^{72}$ This selection is thus completely reverted in the Mukhtașar with its clear focus on revelation and the establishment of a society based on the revealed laws, and its neglect of Muhammad's childhood.

In addition to the Muhammadan light, Ibn 'Abd al-Wahhāb refrains from mentioning other characteristics which could suggest that Muhammad possessed characteristics that transcend those of ordinary humans. When he relates the encounter with the monk Bahīrā, he does not mention the mark of prophethood, and also passes over the veneration which the trees and stones in the vicinity allegedly expressed for Muhammad. Ibn 'Abd al-Wahhāb equally omits the purification and weighing of Muhammad's heart by two angels, an episode which in Ibn Hishām and many other sìra works is associated with the childhood of the Prophet. Tied with this complex is the question of Abū Țālib's status as unbeliever. Katz shows that mawlid texts tend to ascribe a salvific

Bildungsnetzwerke", 478-83. The question of whether Muhammad cast a shadow (Yahṣubī, al-Shifä', 1:731) was very controversial in South Asia but seems not to have been considered relevant among Wahhābīs; on the concept as an expression of psychological essentialism, see Svensson, Människans Muhammed.

69 Katz, Birth, 13-15, 24-29.

$70 \quad$ Katz, Birth, 1-7, 158; Nagel, Allahs Liebling, 301-14.

71 Memon, Ibn Taimīya's Struggle; Katz, Birth, 153-68; Ukeles, "Sensitive Puritan".

72 Katz, Birth, 29-39. 
status to personal relationships to Muhammad and thus consider persons who were attached to him during his childhood as saved. ${ }^{73}$

The lack of any hints to the effect that Muhammad and the prophets possessed personal characteristics that set them apart from ordinary humans is a clear response to the ascriptions of such traits, a phenomenon which is not restricted to devotional literature. A very good example is Qāḍī 'Iyāḍ's assertion that only the physical side of the prophets, including death and decay, is human, whereas their souls and interior (bawātin) resemble that of the angels, as they have to encounter the angels when revelation occurs, which would exceed the capabilities of ordinary humans. ${ }^{74}$ For Ibn 'Abd al-Wahhāb, only the revelation and his actions are aspects which single out Muhammad, and therefore deserve to be noted.

The question remains whether this implies that Ibn 'Abd al-Wahhāb objected to the idea of the Prophetic light, the mark of prophethood, and the purification of the heart as presented by Ibn Hishām, or whether he considered them to be hardly relevant and unsuited for those lacking firm knowledge, who are thus prone to the temptation of shirk. An indication tending towards the latter is the Mukhtașar sirat al-rasūl written by his son 'Abd Allāh b. Muhammad b. 'Abd al-Wahhāb. This more voluminous work lacks the embedding of Muhammad's life in the universal history of prophethood, but repeats many of the episodes his father had considered particularly important with regard to the ontological status of Muhammad. ${ }^{75} \mathrm{He}$ dwells, however, more extensively upon the childhood of Muhammad and follows the sira of Ibn Hishām when it comes to the auspicious signs accompanying begetting, pregnancy, and birth, purifying of the heart, and the encounter with Bahīrā, although the space dedicated to Muhammad before prophethood remains limited in this work as well. ${ }^{76}$ Another indication that Wahhābīs and most probably Ibn 'Abd al-Wahhāb considered these aspects as not necessarily untrue but of little relevance or potentially dangerous is an ordinance issued after the conquest of Mecca which prohibits the recitation of childhood events from the sira exclusively, without his actions as a prophet. ${ }^{77}$

\footnotetext{
73 Katz, Birth, 123-28.

74 Yaḥ̣ubī, al-Shifä̀, 2:224-27; Nagel, Allahs Liebling, 164-66: "unirdischer Wesenskern".

75 Ibn Muḥammad b. 'Abd al-Wahhāb, Mukhtașar, 23-24 (exposure of the private parts during the rebuilding of the Ka'ba), 93 (qișșat al-gharānīq).

76 Ibn Muhammad b. 'Abd al-Wahhāb, Mukhtașar, 13-14, 16; as opposed to that he also mentions that Muhammad's private parts became visible during the reconstruction of the Ka'ba (24) and he affirms qișșat al-gharānīq as well (93).

77 Ibn Muḥammad b. 'Abd al-Wahhāb, "al-Risāla al-thāniya", 47-48; Margoliouth, "Wahhābiyya", 187; Katz, Birth, 171.
} 
With regard to the neglect of the childhood in the Mukhtașar, one further aspect deserves to be mentioned. According to Katz the strong role of female figures in this kind of devotional literature might explain the popularity of this genre among women, as it compensates for the lack of female role models in the Islamic tradition in general. Seen in this perspective, Ibn 'Abd al-Wahhāb's narrative has a very "male" focus. ${ }^{78}$

\subsubsection{Readjusting the Understanding of Ișma}

'Ișma is an attribute which Muslims ascribe to the prophets, and in the Shì'i case also to those whom they regard as their legitimate successors. Frequently, the term is translated as "infallibility", but this choice means siding with one specific understanding of it, which prevailed in Shīi ircles from early on. Many Sunniss, however, objected to such an interpretation, and it became never uncontested among them. Nevertheless, a tendency to understand the term increasingly as being free from sin and error among Sunnīs is unmistakable, and it is a decisive element in the devotion to the Prophet Muhammad flourishing in Sufi circles. It would, however, be wrong to associate this notion with "popular Islam", an expression of "lived religion" or a "low tradition" opposed to a more scripture-based "high tradition". Justifications for this position were formulated by eminent theologians like Fakhr al-Dīn al-Rāzì and by leading fuqahä. The most important example of the latter was articulated by Qâdī 'Iyād. His emphasis on the complete freedom of the Prophet from error and sin is, however, not derived from Sufism, but from Mālikī legal scholarship with its emphasis on the Medinan tradition. ${ }^{79}$

The main opponent of this tendency among Sunnī Muslims in the postclassical period was Ibn Taymiyya, who insisted that ișma does not preclude that prophets say false things or commit minor sins. The term has to be understood in the sense that God guarantees that falsehood will not prevail, and that the prophets will correct what was untrue, and even repent. ${ }^{80} \mathrm{Ibn}$ 'Abd al-Wahhāb follows Ibn Taymiyya on 'ișma and highlights this position within his choice of episodes from the life of Muhammad and the other prophets. The most salient example is the affirmation of qișșat al-gharāniq which appears twice in this work, and also in the shorter "Fī sittat mawādii manqūla min sirat al-nabī" (Six issues reported from the vita of the Prophet). Hence it can be regarded as being of central importance for the overall purpose. Therefore, Shahab Ahmed's position that Ibn 'Abd al-Wahhāb has diluted Ibn Taymiyya's

78 Katz, Birth, 49-50.

79 Rāzī, 'Țmat; Nagel, Allahs Liebling, 183-84.

8o Ahmed, "Ibn Taymiyyah", 71-78, 86-9o, 123. 
stance because he lets Satan put the frivolous words on Muhammad's tongue can be dismissed. With respect to this episode Ibn 'Abd al-Wahhāb follows Ibn Taymiyya, who discussed and affirmed it in his Minhäj al-sunna, and in his special treatise on the topic, which Ibn 'Abd al-Wahhāb apparently was aware of. In contrast to this opinion, the episode was anathema to Qādị 'Iyād, who dismissed it on the basis of the unsoundness of the relevant traditions. In addition, he uses the prophetological circular argument that it cannot be relevant as it contradicts the general image of Muhammad. ${ }^{81}$

Like other ideas of Ibn Taymiyya his position on this event was rediscovered and propagated in the circle of the Kurdish scholar Ibrāhīm al-Kūrānī (1025/1616-1101/1686), which played a decisive role in the resurfacing of puritan doctrines from the eighteenth century onwards, and in the surge of puritan movements in that period: Ibn 'Abd al-Wahhāb was a disciple of the Indian scholar Muḥammad Ḥayāt al-Sindī, a disciple of Ibrāhīm al-Kūrānī's son Abū l-Ṭahir al-Kūrānī. Ibrāhīm had written a treatise on this subject where he considered the idea that the words were laid on Muhammad's tongue by Satan. ${ }^{82}$ Presumably that had led to a renewed interest in the issue in the Hijāz, as witnessed by the extensive discussion of the episode in the chronicle Simțal-nujüm al-'awälifí anb $\bar{a}^{\prime}$ al-awà'il wa-l-tawālì (The chain of sublime stars on reports of the first ones and the followers) by the Hijāzī historian al-'Ișāmì al-Makkī. ${ }^{83}$ Nevertheless it is apparent that the affirmation of the qișșat al-gharāniq was a minority position in the period when the Mukhtașar was written. A rare late example from outside this circle is Murtaḍā al-Zabīdī, who in Ithă $\bar{f}$ al-sāda al-muttaqin, his commentary on Ghazālī's Ihyyā', briefly states that this event happened with reference to Ibn Hajar. ${ }^{84}$ In contrast to that, many scholars otherwise inspired by Ibn Taymiyya do not accept the story. Ibn Qayyim al-Jawziyya does not mention it in Zād al-ma äd, neither does Ibn Kathīr when he deals with the life of the Prophet in his Tärikk: he explicitly refutes the story with reference to Qāḍī Tyāḍ when he elaborates on Q 22:52-54 in his Tafsìr. ${ }^{85}$ His position was adopted by Muhammad $b$. 'Alī al-Shawkānī, an inspiring figure for the puritan Ahl-i Ḥadìth as well as for Rashīd Riḍā, in his tafsìr, Fath al-Qadìr. ${ }^{86}$ As a consequence Rashīd Riḍa objects strongly to Ibn 'Abd al-Wahhāb's

\footnotetext{
81 Yahṣubī, al-Shifä’, 2:288-310.

82 Guillaume, "Lum'at"; Nafi, "Tașawwuf"; Nafi, "Teacher".

83 'Ișāmī, Simț, 327-31; Guillaume, "Lum'a"; Ahmed, "Ibn Taymiyyah", 116; Riexinger, "Der Islam", 42-43.

84 Reichmuth, Murtaḍa al-Zabìdī, 293, 305.

85 Ibn Kathīr, Tafsìr, 1987-9o.

86 Shawkānī, Fath al-Qadìr, 3:628; on the general aspects of his works and the influence on puritan movements, see Haykel, Revival; Riexinger, Sanäullāh Amritsarī, 108-21; Preckel, "Islamische Bildungsnetzwerke", 120-33.
} 
affirmation of the episode in a footnote to "Sittat mawādī" rejection by the latter and by other followers of Ibn Taymiyya from the second half of the nineteenth century onwards it has to be taken into account that the episode played a major role in Christian polemics against Islam. In the most recent Saudi edition of the Mukhtașar the editors have added a footnote where they reject the historicity of the episode with reference to Albānì's criticism of the relevant hadìth material in his Naṣb al-majānīq 'alä qișșat al-gharānīq (Positioning the catapults in direction of the story of the cranes). ${ }^{88}$

Ibn 'Abd al-Wahhāb's presentation of this episode is clearly motivated by his tendency to distinguish between tawhid and the demand for intercession. The fact that it is treated as one of the most important topics in his sira ties in with his stress on the merely human essence of Muhammad. Apart from qișşat al-gharānīq two other episodes are supposed to undermine the idea that prophets are completely free from sin, error, or affliction by Satan. Whereas the discussed episode demonstrates that Muhammad was not protected from satanic interference, even after he had received divine revelations, the story of the restoration of the Kaba implies that the Prophet was not yet aware of what is forbidden and licit, and that he could even be reprimanded by one of his pagan contemporaries. Notably, the idea that Muhammad's genitals were ever seen by anybody is rejected by Qādị 'Iyāḍ, for whom all of the prophets were protected against major transgressions even before receiving the divine message. ${ }^{89}$

The intention to readjust the understanding of ișma with regard to the prophets in general explains as well the choice of the three instances where Ibrāhīm said factually incorrect things as one of the two relevant aspects from the life of this prophet.

\subsubsection{Downplaying the Importance of Miracles}

Miracles have always been an important element in biographies of the Prophet, as well as in other genres associated with his person. Concomitant with the development of the idea of Muhammad's pre-existence and the understanding of ișma as complete freedom from error and sin an incremental tendency with regard to miracles ascribed to Muhammad is undeniable. The little importance attached by Ibn 'Abd al-Wahhāb to miracles in the Mukhtașar is therefore one of the salient characteristics of this text.

87 Ibn 'Abd al-Wahhāb, "Sittat mawāḍī", 105 nı.

88 Ibn 'Abd al-Wahhāb, Mukhtașar, 24n4; Albānī, Naṣb.

89 Yaḥ̦ubī, al-Shifä̀) 1:159, 2:335-39. 
Ibn 'Abd al-Wahhāb wrote the Mukhtașar in an apparent protest against the exuberance of miracles that characterises later biographies of Muhammad, although he does of course not deny miracles as expressions of divine omnipotence. A look at the miracles affirmed by him provides some clues as to how he considers their importance. As the central miracle of affirmation (muјiza) the splitting of the moon is of course mentioned, but rather in passing. So is the mi'ra $\bar{j}$, which is connected to central elements of the revelation, not least to prayer and Last Judgement. But Ibn 'Abd al-Wahhāb's treatment consists of an abridgement of the already rather short treatment in Ibn Qayyim al-Jawziyya's Zād al-ma'a $\bar{d}$, and thus contrasts markedly with the inflation of reports relating to this event in other biographical accounts and in the mawlid poetry, where the ascension serves to illustrate Muhammad's outstanding qualities. ${ }^{90}$ The divine intervention in the Battle of Badr, and the milk which the emaciated ewe of Umm Ma'bad suddenly could provide, contributed to the success of Muhammad's prophetic mission. Only the voice praising Muhammad which could be heard over Mecca at the time of the hijra to Medina is a miracle that serves no other purpose than to glorify Muhammad. Miracles are also mentioned in association with earlier prophets (Nūh and the Flood, Ibrāhīm healing the paralysed hand of the tyrant), with the Ka'ba, which was protected against Abraha's army, and with the family of Muhammad after his death when Muhammad b. Abī Bakr was punished with the loss of his hand for holding it into 'Ā'isha's howdah.

The selection of miracles does not only differ with regard to number but also with regard to quality from the literature reflecting a devotional attitude to Muhammad. Many miracles are supposed to glorify Muhammad, whereas others help to solve concrete problems of the believers, like hunger and sickness, and they are apparently modelled after the miracles of Jesus in the Gospels. Moreover, the miracles are detached from a function related to the success of the prophetic message and they are rather not explained as divine intervention interrupting the ordinary course of matters (kharq al- $\bar{a} d a$ ) but as events emanating from the essence of the prophets, which implies the control of the elements or the ability to communicate with animals. ${ }^{91}$ In this sense baraka is associated with water touched by Muhammad and even his urine and blood,

\footnotetext{
90 On the general conception that these two are the most important miracles of Muhammad, see Gramlich, Wunder, 23.

91 Yahṣubī, al-Shifä̀) 1:617-35.
} 
substances otherwise impure. ${ }^{92}$ Water emerged from between his fingers, ${ }^{93}$ he brought forth water with his baraka to saturate the believers, and multiplied food for them, ${ }^{94}$ and he made his weakened wet nurse Halima able to breastfeed again. ${ }^{95}$ He was venerated by and communicated with animals, plants, and minerals, and he was even able to resurrect dead animals. ${ }^{96}$ Șâlihị goes even further than Qādī 'Iyād in emphasising the centrality of miracles with regard to Muhammad by attributing to each single one the same value as to the Qur'ān. ${ }^{97}$

But Ibn 'Abd al-Wahhāb clarified his stance on the role of miracles in prophecy not only with the help of the selection and omission of material from the tradition. Immediately after mentioning the splitting of the moon, he adds a theological explanation as to why miracles are of so little importance in the life of Muhammad in comparison to that of the other prophets, and what implications this has for the present. With regard to Q 17:59, which is considered a response to the contemporary opponents' challenge to transform silver to gold or to remove the mountains around Mecca, Ibn 'Abd al-Wahhāb points in particular to the miraculous punishments described in the Qurān in which whole nations have perished. With the prophethood of Mūsā and 'Īsā the focus shifted already to repentance and conversion. But with the appearance of Muhammad there occurred a further shift. He was supported by miracles, but central to his prophethood was the institutionalisation of jihäd and the hadd punishments, two devices which the believers are enjoined to apply for the punishment of the obstinate or for forcing them to repent. Nevertheless, one would be mistaken to consider the attitude of Ibn 'Abd al-Wahhāb and other puritans as a kind of rationalism, as in fact some modernists like Sayyid Ahmmad Khān have done. Miracles as expression of divine omnipotence are possible, and they are to be accepted if attested by the Qurān or by sound hadith. That the authority of these sources even applies to matters of cosmology led to negative responses to modern science in the late nineteenth and early twentieth centuries. ${ }^{98}$

\footnotetext{
92 Yaḥ̦ubī, al-Shifầ, 1:157-59, 249-50.

93 Yaḥ̦ubī, al-Shifä̀) 1:550-54.

94 Yaḥ̣ubī, al-Shifä, 1:555-62.

95 Katz, Birth, 41.

96 Yaḥ̦ubī, al-Shifä', 1:563-616; Nagel, Allahs Liebling, 105-6, 202, 287-88, 293, 323.

$97 \quad$ Nagel, Allahs Liebling, 296.

98 Riexinger, “How Favourable?”; Riexinger, “Ibn Taymiyya's Worldview”; Tamer, "Curse of Philosophy".
} 
One of the few non-military events in the Medinan phase which Ibn 'Abd al-Wahhāb deems worthy of mention is the so-called necklace affair when 'Á'isha lagged behind the campaign and returned to it in the company of Șāfwān b. Mu'atțal. In spite of her excuse that she was searching for a necklace she had lost and was discovered by the young companion, who accompanied her to protect her, numerous șahāaba, most prominently 'Alī, accused her of zinā and demanded her to be punished accordingly, putting stress on Muhammad who tried to avoid a decision. According to the standard account, the problem was solved for Muhammad by the revelation of Q 24:11-26, which in addition to the punishment of adulterers contained the punishment of those who falsely accuse others of $z$ in $\bar{a}^{99}$

The reason for Ibn 'Abd al-Wahhāb's choice of this episode is most likely that Muhammad's wavering until the revelation could serve him as argument in another issue puritans had with the devotional attitude of the Prophet. This was the question whether "knowledge of the hidden" ('ilm bi-l-ghayb) was one of the ontological attributes of Muhammad, against which they maintained that any such knowledge could only result from divine revelation. In a moderate form this idea can be found with Qāḍi 'Iyāḍ: he does not claim that the prophets had full knowledge of worldly affairs as their preoccupations are the hereafter and the rules of the shari $a{ }^{100}$ and information of future and past events are described as $i j \bar{a} z,{ }^{101}$ but he claims that the knowledge about the revelation (shari $\left.{ }^{-} a\right)$ has been complete from the start ${ }^{102}$ as exemplified by neither Ibrāhīm nor Muhammad ever being in doubt. ${ }^{103}$

Ibn 'Abd al-Wahhāb never elaborated more explicitly on this issue. Other early Wahhābi texts, however, corroborate the impression that the nature of Muhammad's knowledge was a relevant topic at that time. His son explicitly connects the episode to this question ${ }^{104}$ and his grandson 'Abd al-Rahmmān b. Hasan insists that Muhammad was only aware of future events including "the Hour" when God had revealed them to him. ${ }^{105}$

\footnotetext{
99 Schoeler, Charakter, 119-70.

100 Yahṣubī, al-Shifä', 2:269-70.

101 Yahṣubī, al-Shifä', 1:518-21.

102 Yaḥsubī, al-Shifä̀, 2:272.

103 Yaḥ̣ubī, al-Shifä’, 2:231-33, 236-37.

104 Ibn Muḥammad b. 'Abd al-Wahhāb, Mukhtaṣar, 279.

105 'Abd al-Rạ̣mān b. Hasan, "Bayān", 253-54.
} 


\subsubsection{Delegitimisation of the Awliyā'}

Ibn 'Abd al-Wahhāb's attempt to undermine the belief in the special status of Muhammad implies an attack on the claims of the awliy $\bar{a}^{3}$ whose exalted status is inferior to that of the Prophet, but nonetheless derived from it. By depriving the person of Muhammad of all superhuman aspects not related to revelation and divine intervention to support it, any claims that would lift the saints out of the flock of ordinary humans is implicitly denied. But Ibn 'Abd al-Wahhāb does not restrict himself to attacking the concept of sainthood indirectly, as his presentation of Musaylima can be seen as a caricature of what was expected from awliy $\vec{a}$ and often claimed for them by themselves or at least by their entourage. Whereas it is commonplace that miracles with unintended consequences occur with pseudo-prophets and expose them as liars, ${ }^{106} \mathrm{Ibn}$ 'Abd al-Wahhāb deselected a tradition of reports where Musaylima responds to requests to effect miracles "like Muhammad". Instead, he opted with Kalā'ī for a tradition that does not presuppose that the most remarkable aspect of Muhammad was that he effected miracles providing relief in worldly matters.

Ibn 'Abd al-Wahhāb's caricature does not aim at "official" Sufi doctrines. Sufi literature treats karāmāt in association with secrecy or insecurity of awliy $\bar{a}^{\text {, }}$ about their status, whereas brazen self-advertisement is denounced. ${ }^{107}$ In contrast it presents a realistic assessment of what the popularity of the awliy $\bar{a}$ was based on in real life. Miracles of healing were associated with awliy $\bar{a}$ ' and considered a reason for visiting graves from early on, ${ }^{108}$ and they are an important feature of hagiographic literature. ${ }^{109}$

\subsection{The Vision of Muhammad and the Concept of History}

The sirra never developed into an official discipline within traditional Muslim scholarship, and actually many of the works dedicated to the life and characteristics of the Prophet were written quite late. ${ }^{110}$ Nevertheless, it would be false to downplay the importance of the genre. Biographies of the Prophet are supposed to function as fiction of coherence in the sense of Assmann, that is, a text or narrative supposed to demonstrate the "connection between ... the whole and the parts". 11 With regard to the function of the sira genre in the

\footnotetext{
106 Gramlich, Wunder, 57.

107 Gramlich, Wunder, 6o-63.

108 Beránek and Ťupek, Temptation, 29, 37-40.

109 Gramlich, Wunder, 306-15.

110 Schöller, Mohammed, 86-87.

111 Assmann, Ägypten, 17-18.
} 
Islamic context this means that the purpose is to explain Muhammad's role in universal history, usually in a kind of Heilsgeschichte (salvation history), in order to make the related norms plausible. ${ }^{12}$ The targeted audience were not least the laymen who listened to recitations - combined with explanations from the sira in edifying sessions in mosques. In this respect the Mukhtașar resembles other biographies of the Prophet, whereas it differs radically with regard to purpose and content of the fiction of coherence.

\subsubsection{Transformative, Not Thaumaturgical}

It can be problematic to identify emic categories in a religious discourse with theoretical concepts from the sociology of religion. In the particular case of this sira-cum-pamphlet, we indeed find Ibn 'Abd al-Wahhāb juxtaposing two religious attitudes that practically coincide with goals of religious actions that the sociologist of religion Stephen Sharot has labelled as "thaumaturgic" and "transformative". Whereas with the help of thaumaturgic actions "special dispensation and release are sought from specific ills within a nature and a society whose basic features are not expected to change," the goal of transformative religious action "is to produce a fundamental or pervasive change in nature, society, and individual being or nonbeing". ${ }^{13}$ Sharot does not consider both functions mutually exclusive; instead he shows that the thaumaturgic and the transformative have in the course of history often been combined in compromises if not syntheses. He does not identify these goals with any specific religions either but rather asks which role these goals play in different religious traditions and how they can be related to elite-laymen relations in these religions. A common feature of the tension between the transformative and the thaumaturgical is the delegation of the thaumaturgical function to beings inferior to the "high gods", but more susceptible to the supplications and demands of humans as well as to their rewards. ${ }^{114}$

Ibn 'Abd al-Wahhāb was far from formulating such a synthesis. In contrast he defines a transformative understanding of Islam as mandate to order society according to the blueprint of the divine law. To this he juxtaposes a misunderstanding of religion as a means to alleviate life. Hence Ibn 'Abd al-Wahhāb does not only reject the cult of graves and the veneration of saints, because they are directed at beings inferior to God, but objects to such practices because they are based on a faulty assumption about the purpose of religion. He makes this

\footnotetext{
112 Schöller, Exegetisches Denken, 32.

113 Sharot, Comparative Sociology, 36; the other two goals, "nomic" (to maintain the order of the world) and "extrinsic" (non-religious goals), are not relevant in our context.

114 Sharot, Comparative Sociology, 247-29.
} 
explicit by quoting Hasan al-Bașrī in the prologue: "belief is not adornment (tahallin) and desire (tamannin), it weighs heavily on the heart, and deeds bear witness to it."115 Ibn 'Abd al-Wahhāb himself repeats again and again that belief manifests itself in correct acts. The correct relation to Muhammad is thus an obligation. In contrast to this, the devotional attitude to Muhammad, and the relations to the saints modelled after it, have the character of a deal within an "economy of salvation" where baraka is paid for with devotion. ${ }^{116}$

The Mukhtașar addresses Ibn 'Abd al-Wahhāb's concern about a misconception regarding the person of Muhammad on the basis of the corruption of religion. Where Muhammad should be a model for emulation, he has been transformed into the supreme thaumaturge. ${ }^{117}$ Miracles, of which only a few are true and relevant according to Ibn 'Abd al-Wahhāb, have overgrown the message. Therefore, he straightens them out of the narrative. His attitude towards miracles is far from Islam-specific but has parallels in other religious traditions, where reformist currents wanted to establish a clear primacy of the transformative over the thaumaturgical aspects by establishing the primacy of the word ("rede") over the miraculous deeds ("wercke", "wunderthaten"), as Luther does in his preface to the New Testament. ${ }^{118}$ This is most aptly illustrated by one episode from the Medinan phase. In a competition between the two poet brothers Muslim Bujayr and pagan Ka'b b. Zuhayr, the latter finally submits, becomes a Muslim, and composes the panegyric on Muhammad, titled Bānat Su'âd. The poem is characterised by the imagery of jāhiliyya poetry and emphasises the warrior qualities of Muhammad. This fits perfectly into Ibn 'Abd al-Wahhāb's concept, who hence quotes numerous lines. No mention, however, is made of the cloak Muhammad allegedly bestowed on Kacb. The legend of this cloak implies the transmission of Muhammad's baraka to privileged believers, and it does not least provide the starting point for Būṣīì's Qasidat al-Burda, one of the most popular texts glorifying the thaumaturgical Muhammad. ${ }^{119}$ The implicit attack on the panegyric, devotional poetry with its strong emotive character can be interpreted as a statement against what Harvey Whitehouse has defined as the imagistic mode of religiosity, which leads to arousal through relatively rare and highly emotive rituals. The mode of religiosity Ibn 'Abd al-Wahhāb's understanding of Islam represents is

\footnotetext{
115 Ibn 'Abd al-Wahhāb, Mukhtașar, 28.

116 Katz, Birth, 63-103; Svensson, Människans Muhammed, 176-93.

117 On this tension, see also Svensson, Människans Muhammed, 98-101.

118 Luther, "Vorrede", 11; I thank my colleague Hans Jørgen Lundager for alerting me to this parallel.

119 Nagel, Allahs Liebling, 320-21: "Der inhaltlich, insbesondere der dogmatische Abstand zwischen beiden Mantelgedichten ist riesig"; Svensson, Människans Muhammed, 162-75.
} 
as opposed to that doctrinal, based on routinised, less emotive practices supposed to support the internalisation of norms. ${ }^{120}$

The reduction of the miraculous in the sira has one more function. It is supposed to stress the commonality between Muhammad and ordinary humans in all matters not related to revelation. It thus also serves the purpose to demonstrate that his actions not related to revelation can be emulated. This aspect has to be seen in connection with Ibn 'Abd al-Wahhāb's concept of history, the final aspect of our discussion.

\subsubsection{Back and Forth, Not a Radical Shift: The Concept of History and the Implicit Mandate for Action}

In his analysis of the veneration of Muhammad, Tilman Nagel has demonstrated that literature dedicated to the devotion of Muhammad divides history sharply up in two radical different phases, the darkness before and the "new eon" illuminated by the Muhammadan light. ${ }^{121}$ As opposed to this, the concept of history underlying the Mukhtașar is quite pessimistic, with a tendency towards the negation of a Heilsgeschichte.

The life of Muhammad is part of a sequence of continuous movements backwards and forwards. Ādam had been instructed in tawhìd but generations later, his descendants succumbed to the veneration of their pious ancestors and established paganism. Nūh was the first prophet assigned with the task to call for a return to tawhid. Divine punishment led to a re-establishment of Islam, which, however, was succeeded by further relapses, only to be corrected by further prophets within a specific regional setting. With Mūsā and 'Īsā the purpose of divine intervention shifted from punishment to confirmation. With Muhammad not only prophecy came to an end, but the establishment of the divine order was from now on imposed on the believers, with the example of Muhammad's founding of an Islamic society by the means of jihäd and the hadd punishments. Muhammad is not the central purpose of creation in this concept of history, contrary to a common opinion expressed in the unsound but often-quoted hadīth qudsī "law lā-ka mā khalaqtu l-aflāka"."22 Instead, he has a function within creation and for the created beings.

That the re-establishment of Islam would constantly become necessary is demonstrated with various examples. Already during Muhammad's lifetime the Banū Hawāzin apostatised, and after his death the Muslims had to face

\footnotetext{
120 Whitehouse, Arguments; Katz, Birth, 104-23, 128-39; Svensson, Människans Muhammed, 264-75.

121 Nagel, Allahs Liebling, 253-54.

122 Nagel, Allahs Liebling, 326-27.
} 
the challenge of the large-scale defection known as ridda. Thereafter various heretics and pseudo-Muslim rulers appeared but were defeated by scholars and/or military and political leaders. The clue to the interpretation of these examples is delivered by the hadith "Islam began as something strange", which also exists in a longer version, which concludes with a blessing of those who re-establish (yuṣlihūna) what the people have corrupted from Muhammad's sunna. By an implicit description of the present times in the framework of the terminology used for the pre-Islamic jāhiliyya, Ibn 'Abd al-Wahhāb's concept of history emphasises the necessity to follow the model of Muhammad and to re-establish the divine order. ${ }^{123}$

And this is the junction where prophetology and the concept of history merge: whereas the clearing of the image of Muhammad of every superhuman aspect is supposed to demonstrate that this act of emulation is feasible, the description of the present shall highlight that this emulation is urgent.

\section{Bibliography}

\section{Primary Sources}

'Abd al-Raḥmān b. Ḥasan. "al-Bayān al-muhạaja fì l-radd 'alā l-lajja", in M. Rashīd Riḍaā, ed., Majmū'at al-tawhīd al-najdiyya, Cairo, Mațba'at al-Manār, 1927, 224-82.

Albānī, M. N. Naṣb al-majānīq li-nasaf qișsat al-gharānīq, Damascus, Manshūrāt al-Maktab al-Islāmī, $195^{2}$.

Ibn 'Abd al-Wahhāb, M. "Fī sittat mawāẹi ' manqūla min sīrat al-nabī”, in M. Rashid Riḍaā, ed., Majmū'at al-tawhīd al-najdiyya, Cairo, Mațba'at al-Manār, 1927, 103-110.

Ibn 'Abd al-Wahhāb, M. Mukhtașar sīrat al-rasūl, Cairo, al-Mațba'a al-Yūsufiyya, 1956 [2004 edition: ed. U. Kāmil, Mecca, Maktabat Nizār Mușțafā al-Bāz].

Ibn al-Jawzī, 'A. al-Wafā' bi-ahwāal al-Muștafā, Cairo, Dār al-Kutub al-Ḥāditha, 1966.

Ibn al-Jawzī, 'A. al-Muntazam fì ta'rīkh al-mulūk wa-l-umam, 19 vols, ed. M. 'Abd al-Qādir 'Ațā and N. Zarzūr, Beirut, Dār al-Kutub al-'Ilmiyya, 1995.

Ibn Hishām. Sìra, 1:403-8, in F. Wüstenfeld, ed., Das Leben Muhammed's nach Muhammed Ibn Ishâk. Bearb. Von Abd el-Malik Ibn Hischâm. Aus den Hs. zu Berlin, Leipzig, Gotha u. Leyden, Göttingen, Dieterich, 1858.

123 Thus, the text is an example for the monotheist self-perception as "counter-religion" (Gegenreligion) as a radical break with the polytheist past and for the recurrent emergence of puritan movements within monotheist religions which claim to reenact this secession after periods of decay: Assmann, Mosaische Unterscheidung, 26, 53; Assmann, Totale Religion, $16-17$. 
Ibn Kathīr. Tafsīr al-Qur'ān al-'azīm, ed. 'A. al-Ḥ. b. Maḥmūd and M. b. N. Abī Jabal, Cairo, Dār Ṣādir, 2010.

Ibn Muḥammad b. 'Abd al-Wahhāb, 'A. "al-Risāla al-thāniya", in S. b. Suḥmān, ed., al-Hadya al-sunniyya, Cairo, Mațba'at al-Manār, 1925, 35-50.

Ibn Muḥammad b. 'Abd al-Wahhāb, 'A. Mukhtașar sīrat al-rasūl, Cairo, 1956 [reprint Riyadh, 1976].

Ibn Qayyim al-Jawziyya. Zād al-māād fì hady khayr al-ibād Muhammad khātim al-nabiyyīn wa-imām al-mursalīn, 5 vols, Cairo, al-Mațba'a al-Mișriyya, 1959.

Ibn Sacd. Tabaqāt, vol. 1, in E. Mittwoch et al., eds, Biographien Muhammeds, seiner Gefährten und der späteren Träger des Islams, bis zum Jahre 230 der Flucht, Leiden, Brill, 1905 .

Ibn Tūmart. Kitāb a'azz, in I. Goldziher, ed., Le livre d'Ibn Toumart, Alger, 1903.

'Ișāmī al-Makkī, A. Șimț al-nujūm al-'awālī fì anbā' al-awā̉il wa-l-tawālī, ed. 'Ā. A. 'Abd al-Mawjūd and 'A. M. Mu'awwad, Beirut, Dār al-Kutub al-'Ilmiyya, 1998.

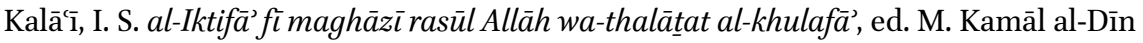
'Izz al-Dīn 'Alī, Beirut, 'Ālam al-Kutub, 1997.

Qasțallānī, A. B. al-Mawāhib al-laduniyya bi-l-minah al-muḥammadiyya, Beirut, Dār al-Kutub al-'Ilmiyya, 1996.

Rāzī, F. D. Tṣmat al-anbiyā', Cairo, 1986.

Shawkānī, M. Faṭ̣ al-Qadīr, Mansoura, Dār al-Wafā', n.d.

Yaḥ̦ubī, 'I. Shifā' bi-ta'rīf ḥuqūq al-Muștafā, 2 vols, ed. M. Amīn Qurra, Damascus, Maktabat al-Fārābī, [1972].

Yasin, K. "Powerful Lecture - Khalid Yasin Ghuraba (Strangers)", YouTube, 17 May 2012. Accessed 27 February 2020. www.youtube.com/watch?v=haPk5B_Z9TM.

\section{Secondary Literature}

Abou El Fadl, K. Rebellion and Violence in Islamic Law, Cambridge, Cambridge University Press, 2001.

Ahmed, S. "Ibn Taymiyyah and the Satanic Verses", Studia Islamica 87 (1998), 67-124.

Al Makin. Representing the Enemy: Musaylima in Muslim Literature, Frankfurt, Lang, 2010.

Assmann, J. Ägypten: Eine Sinngeschichte, Darmstadt, Wissenschaftliche Buchgesellschaft, 1996.

Assmann, J. Die Mosaische Unterscheidung oder der Preis des Monotheismus, Munich and Vienna, Hanser, 2003.

Assmann, J. Totale Religion: Ursprünge und Formen puritanischer Verschärfung, Vienna, Picus, 2016.

Beránek, O., and P. Ťupek. The Temptation of Visiting Graves in Salafi Islam: Iconoclasm, Destruction and Idolatry, Edinburgh, Edinburgh University Press, 2018. 
Boberg, D. Ägypten, Nağd und der Hiğāz: eine Untersuchung zum religiös-politischen Verhältnis zwischen Ägypten und den Wahhabiten, 1923-1936, anhand von in Kairo veröffentlichten pro- und antiwahhabitischen Streitschriften und Presseberichten, Frankfurt, Lang, 1991.

Brockelmann, C. Geschichte der arabischen Litteratur, Supplementband II, Leiden, Brill, 1938.

Croitoru, J. "Der Gründer des Wahhabismus: Verherrlichte Gewalt", Frankfurter Allgemeine Zeitung 137/3 (2016), N3.

Dunlop, D. M. “The Spanish Historian Ibn Hubaish", Journal of the Royal Asiatic Society 73/4 (1941), 359-62.

Gramlich, R. Die Wunder der Freunde Gottes: Theologien und Erscheinungsformen des islamischen Heiligenwunders, Wiesbaden, Steiner, 1987.

Guillaume, A. "al-Lum'at as-saniyy a fi taḥqì al-ilq à fì l-umniyya by Ibrāhīm al-Kūrān̄̄", Bulletin of the School of Oriental and African Studies 20 (1957), S. 291-303.

Halm, H. Shi ism, New York, Columbia University Press, 2004.

Haykel, B. Revival and Reform in Islam: The Legacy of Muhammad al-Shawkani, Cambridge, Cambridge University Press, 2003.

Katz, M. H. The Birth of the Prophet Muhammad: Devotional Piety in Sunni Islam, London, Routledge, 2007.

Laoust, H. "Une fetwâ d'Ibn Taimīya sur Ibn Tūmart", Bulletin de l'Institut Français d'Archéologie Orientale 59 (1960), 157-84.

Luther, M. "Vorrede auf das neue Testament", in D. Martin Luthers Werke, Abt. 3 Bd. 6. Bd. 6. Das Neue Testament, erste Hälfte (Evangelien und Apostelgeschichte), ed. G. Bebermeyer and K. Drescher, Weimar, Böhlau, 1929, 2-13.

Margoliouth, D. S. "Wahhābiyya", Encyclopaedia of Islam, Leiden/Leipzig, Brill/ Harrassowitz, 1934, IV, 1175-80.

Memon, U. Ibn Taimiya's Struggle against Popular Religion: With an Annotated Translation of His Kitāb iqtị̣ā’ aṣ-șirāṭ al-mustaqīm mukhālafat aṣhāb al-jahīm, The Hague, Mouton, 1976.

Michot, Y. Muslims under Non-Muslim Rule, Oxford and London, Interface Publications, 2006.

Nafi, B. "Tașawwuf and Reform in Pre-modern Islamic Culture: In Search of Ibrāhīm al-Kūrān̄̄", Welt des Islams 42 (2002), 307-55.

Nafi, B. "A Teacher of Ibn 'Abd al-Wahhāb: Muhammad Hayāt al-Sindī and the Revival of Ashāb al-Hadìth's Methodology", Islamic Law and Society 13 (2006), 208-41.

Nagel, T. Allahs Liebling: Ursprung und Erscheinungsformen des Mohammedglaubens, Munich, Oldenbourg, 2008.

Pellat, C. "al-Kalā‘̄ì, Abu 'l-Rabī‘ Sulaymān b. Mūsā b. Sālim al-Ḥimyarī al-Balansī, Often Known as Ibn Sālim al-Kalāc̄̄”, In C. E. Bosworth et al., eds, Encyclopaedia of Islam, Second Edition, Leiden, Brill, 1974, v, 468. 
Peskes, E. Muhammad b. 'Abdalwahhāb (1703-1792) im Widerstreit: Untersuchungen zur Rekonstruktion der Frühgeschichte der Wahhābīya, Stuttgart, Steiner, 1993.

Preckel, C. "Islamische Bildungsnetzwerke und Gelehrtenkultur im Indien des 19. Jahrhunderts: Muhammad Ṣiddīq Ḥasan Huān (st. 1890) und die Entstehung der Ahl-e Hadīt-Bewegung in Bhopal", PhD diss., Ruhr University Bochum, 2005. Accessed 27 February 2020. https://hss-opus.ub.ruhr-uni-bochum.de/opus4/front door/deliver/index/docId/2036/file/diss.pdf.

Reichmuth, S. The World of Murtadā al-Zabidi: Life, Networks and Writings, Cambridge, E. J. W. Gibb Memorial Trust.

Riexinger, M. Sanāullāh Amritsarī (1867-1948) und die Ahl-i Hadīs im Punjab unter britischer Herrschaft, Würzburg, Ergon-Verlag, 2004.

Riexinger, M. "How Favourable Is Puritan Islam to Modernity? A Case Study on the Ahl-i Hadis in British India", in G. Beckerlegge, ed., Colonialism, Modernity and Religious Identities: Religious Reform Movements in South Asia, New Delhi and New York, Oxford University Press, 2008, 147-65.

Riexinger, M. "Ibn Taymiyya's Worldview and the Challenge of Modernity: A Conflict among the Ahl-i Hadith in British India", in B. Krawietz and G. Tamer, eds, Islamic Theology, Philosophy and Law: Debating Ibn Taymiyya and Ibn Qayyim al-Jawziyya, Berlin, De Gruyter, 2013, 493-517.

Riexinger, M. "Rendering Muhammad Human Again: The Prophetology of Muhammad b. 'Abd al-Wahhāb (1703-1792)", Numen 6o (2013), 103-18.

Riexinger, M. "Der Islam begann als Fremder, und als Fremder wird er wiederkehren': Muḥammad b. 'Abd al-Wahhābs Prophetenbiographie Muhtașar sīrat ar-rasūl als Programm und Propaganda", Welt des Islams 55 (2015), 1-61.

Robinson, C. Islamic Historiography, Cambridge, Cambridge University Press, 2003.

Rubin, U. "Pre-existence and Light: Aspects of the Concept of Nūr Muhammad", Israel Oriental Studies 5 (1975), 62-119.

Rubin, U. "Abū Țālib", in K. Fleet et al., eds, Encyclopaedia of Islam, Third Edition (online), Leiden, Brill, 2009.

Said, B. "Die Konferenz zur Mardin-Fatwa Ibn Taimìyas und zwei Repliken hierauf aus der jihadistischen Szene", in T. Seidensticker, ed., Zeitgenössische islamische Positionen zu Koexistenz und Gewalt, Wiesbaden, Harrassowitz, 2011, 99-127.

"Salafitische Initiativen: Stolz darauf fremd zu sein", 9 January 2010. Accessed 27 February 2020. www.ufuq.de/salafitische-initiativen-stolz-darauf-fremd-zu $-\operatorname{sein} /$.

Schoeler, G. Charakter und Authentie der muslimischen Überlieferung über das Leben Mohammeds, Berlin, De Gruyter, 1996.

Schöller, M. Exegetisches Denken und Prophetenbiographie: Eine quellenkritische Analyse der Sira-Überlieferung zu Muhammads Konflikt mit den Juden, Wiesbaden, Harrassowitz, 1998. 
Schöller, M. "Biographical Essentialism in the Life of Muhammad in Islam", in A. Schüle, ed., Biographie als religiöser und kultureller Text, Münster, LIT-Verlag, 2002, 153-72.

Schöller, M. Mohammed: Leben und Wirkung, Frankfurt, Suhrkamp, 2008.

Sells, M. A., and M. J. Sells. "Bānat Su'ād: Translation and Introduction", Journal of Arabic Literature 21/2 (1990), 140-54.

Sharot, S. Comparative Sociology of World Religions: Virtuosi, Priests, and Popular Religion, New York, New York University Press, 2001.

Svensson, J. Människans Muhammed, Stockholm, Molin \& Sorgenfrei, 2015.

Tamer, G. "The Curse of Philosophy: Ibn Taymiyya as a Philosopher in Contemporary Islamic Thought", in B. Krawietz and G. Tamer, eds, Islamic Theology, Philosophy and Law: Debating Ibn Taymiyya and Ibn Qayyim al-Jawziyya, Berlin, De Gruyter, 2013, 329-74.

Tottoli, R. Biblical Prophets in the Qur'ān and Muslim Literature, Richmond, Curzon, 2001.

Ukeles, R. M. “The Sensitive Puritan: Revisiting Ibn Taymiyya's Approach to Law and Spirituality in Light of 2oth-Century Debates on the Prophet's Birthday (mawlid al-nab̄̄)", in S. Ahmed and Y. Rapoport, eds, Ibn Taymiyya and His Times, Karachi, Oxford University Press, 2010, 319-37.

Urvoy, D. “La pensée d' Ibn Tūmart”, Bulletin des Etudes Orientales 27 (1974), 19-44. van Ess, J. Theologie und Gesellschaft im 2. und 3. Jahrhundert der Hidschra: Eine Geschichte des religiösen Denkens im frühen Islam, vol. 2, Berlin, De Gruyter, 1992. van Ess, J. Theologie und Gesellschaft im 2. und 3. Jahrhundert der Hidschra: Eine Geschichte des religiösen Denkens im frühen Islam, vol. 4, Berlin, De Gruyter, 1997.

Vuckovic, B. O. Heavenly Journeys, Earthly Concerns: The Legacy of the Miraj in the Formation of Islam, New York and London, Routledge, 2005.

Whitehouse, H. Arguments and Icons: Divergent Modes of Religiosity, Oxford, Oxford University Press, 2000. 